\title{
Delayed Ettringite Formation in Fly Ash Concrete under Moist Curing Conditions
}

\author{
Zhuqing Yu, Jian Ma, Hu Shi, and Xiaodong Shen \\ College of Materials Science and Engineering, Nanjing Tech University, China \\ Guang Ye \\ Microlab, Faculty of Civil Engineering and Geosciences, Delft University of Technology, Netherlands
}

\begin{abstract}
During the hydration of cement, tricalcium aluminate $\left(C_{3} A\right)$ reacts with gypsum and forms ettringite (AFt). Once all gypsum is consumed, ettringite can further react with remaining $C_{3} A$ and form monosulfate (AFm) at $1-2$ days. Normally, at early ages, ettringite all transfers to AFm phase. After several months or years, ettringite can form again if a new source of sulfate becomes available in the pore solution of the paste, viz. delayed ettringite formation. In previous study, it was found that delayed ettringite forms in Portland cement concrete when the concrete samples were cured under moist conditions, i.e., without external sulfate phase. This delayed ettringite formation may result in the decrease of resistance of Portland cement concrete to chloride penetration. After that, it was found that ettringite, viz. delayed ettringite formation, also generated in fly ash concrete. The formation of ettringite, however, has no obvious influence on the resistance of fly ash concrete to chloride penetration.
\end{abstract}

\section{INTRODUCTION}

During the hydration of cement, tricalcium aluminate $\left(\mathrm{C}_{3} \mathrm{~A}\right)$ reacts with gypsum and forms ettringite (AFt: $\mathrm{C}_{6} \mathrm{AS}_{3} \mathrm{H}_{32}$ ) [see Eq. (1)]. Once all gypsum is consumed, ettringite can further react with remaining $\mathrm{C}_{3} \mathrm{~A}$ and form monosulfate (AFm: $\mathrm{C}_{4} \mathrm{AS}_{\mathrm{S}}{ }_{12}$ ) [see Eq. (2)].

$$
\begin{gathered}
\mathrm{C}_{3} \mathrm{~A}+3 \mathrm{C}_{\underline{S}} \mathrm{H}_{2}+26 \mathrm{H} \rightarrow \mathrm{C}_{6} \mathrm{AS}_{3} \mathrm{H}_{32} \\
2 \mathrm{C}_{3} \mathrm{~A}+\mathrm{C}_{6} \mathrm{AS}_{3} \mathrm{H}_{32}+4 \mathrm{H} \rightarrow 3 \mathrm{C}_{4} \mathrm{AS}_{12}
\end{gathered}
$$

At later stages (after several months or years), ettringite can form again in Portland cement concrete, viz. delayed ettringite formation (DEF) if (1) a new source of sulfate becomes available in the pore solution of the paste (Collepardi, 2001; Stark \& Bollmann, 1999) [see Eq. (3)] and (2) the concrete mixtures are under steam curing conditions $\left(>70^{\circ} \mathrm{C}\right)$ with subsequent moist conditions (Ludwig \& Heinz, 1985). In general, DEF accompanies with cracks formation and deterioration of concrete structures (Collepardi, 2001).

$$
\begin{aligned}
& \left(3 \mathrm{CaO} \cdot \mathrm{Al}_{2} \mathrm{O}_{3}\right) \cdot \mathrm{CaSO}_{4} \\
& \left.\cdot 12 \mathrm{H}_{2} \mathrm{O}+6 \mathrm{Ca}(\mathrm{OH})_{2} \rightarrow 3\left(3 \mathrm{CaO} \cdot \mathrm{Al}_{2} \mathrm{O}_{3}\right) \cdot 3 \mathrm{CaSO}_{4} \cdot 32 \mathrm{H}_{2} \mathrm{O}\right) \\
& +8\left(\mathrm{CaSO}_{4} \cdot 2 \mathrm{H}_{2} \mathrm{O}\right)
\end{aligned}
$$

In previous study, it was found that DEF occurred in Portland cement concrete at later ages when the concrete mixtures were cured in a fog room $\left(20^{\circ} \mathrm{C}\right.$; $100 \%$ humidity), i.e., without external sulfate attack (Yu, Ye, \& Shen, 2015). And this delayed ettringite formation resulted in the decrease of resistance of Portland cement concrete to chloride penetration. In this study, the reaction products and microstructure of fly ash concrete were investigated by using X-ray diffraction (XRD) and environmental scanning electron microscope (ESEM). The results show that the delayed ettringite also generates in fly ash concrete. Rapid chloride migration (RCM) test was used to determine the resistance of fly ash concrete to chloride penetration. The results indicate that the formation of ettringite, however, has no obvious influence on the resistance of fly ash concrete to chloride penetration.

\section{EXPERIMENTS}

\subsection{Raw materials}

The materials used in this study are Portland cement (CEM I $42.5 \mathrm{~N})(\mathrm{ENCl}$, the Netherlands), fly ash, aggregate (the maximum size of $16 \mathrm{~mm}$ ), and tap water. Table 1 shows the chemical compositions of Portland cement and fly ash. For fly ash, concrete fly ash dosages were 30 and $50 \%$ by weight, based on the total weight of the binder. The water/binder ratios were $0.4,0.5$, and 0.6 .

\subsection{Experimental methods}

X-ray diffraction (XRD) analysis was used to identify the hydration products of concrete. The dried concrete samples were gently ground by hand until the particle size was smaller than $125 \mu \mathrm{m}$. After grinding, the powder samples used for XRD were placed in an aluminium sample holder. XRD analyses were performed using a Philips X' pert diffractometer system with $\mathrm{Cu} \mathrm{K} \alpha$ radiation. Scans were run from 
5 to $70^{\circ} 2 \theta$, with a step size of $0.02^{\circ} 2 \theta$ and a dwell time of $2 \mathrm{~s}$ per step.

Table 1. Chemical compositions of Portland cement and fly ash (\% by mass).

\begin{tabular}{lcc}
\hline Chemical composition & CEM I 42.5 N & Fly ash \\
\hline $\mathrm{SiO}_{2}$ & 20.36 & 48.40 \\
$\mathrm{Al}_{2} \mathrm{O}_{3}$ & 4.96 & 31.40 \\
$\mathrm{CaO}$ & 64.40 & 7.14 \\
$\mathrm{Free}-\mathrm{CaO}$ & 0.60 & - \\
$\mathrm{Fe}_{2} \mathrm{O}_{3}$ & 3.17 & 4.44 \\
$\mathrm{P}_{2} \mathrm{O}_{5}$ & 0.18 & 1.90 \\
$\mathrm{~K}_{2} \mathrm{O}$ & 0.64 & 1.64 \\
$\mathrm{MgO}_{\mathrm{SO}}$ & 2.09 & 1.35 \\
$\mathrm{SO}_{3}$ & 2.57 & 1.18 \\
$\mathrm{Na}_{2} \mathrm{O}$ & 0.14 & 0.72 \\
$\mathrm{Total}$ & 99.11 & 98.17 \\
\hline
\end{tabular}

Environmental scanning electron microscope (ESEM) was used to observe the morphology of hydration products by performing secondary electron (SE) mode (for instance, the needle-shaped ettringite in concrete). The concrete specimens for SE image observations were split into several small pieces by hammer and dried in a vacuum machine. After drying (around 2 days), carbon coating was applied on the surface of samples to create a conductive layer in order to avoid charging of concrete samples and to improve the SE signal.

Rapid chloride migration (RCM) test was used to determine the resistance of concrete to chloride ingress. The concrete samples were cast in standard cylindrical mould with the dimension of $\Phi 100 \mathrm{~mm} \times 300 \mathrm{~mm}$.
After demoulding, the specimens were cured in a fog room until preconditioning for testing in 28, 91, 180, 365, 730, and 1095 days. NT Build 492 method was used to determine the chloride migration coefficient of concrete (DRCM) from non-steady-state migration experiments (NT Build 492, 1999).

\section{RESULTS}

\subsection{XRD results}

Figure 1 shows the XRD patterns of fly ash concrete $(30 \%$ fly ash; w/c $=0.4)$ at an age of 3 years. The characteristic peaks of ettringite $\left(2 \theta=9.09^{\circ}\right)$ is clearly detected, that is, confirmed with the XRD results of the Portland cement concrete (Yu et al., 2015).

\subsection{SE image observations}

Figure 2 shows the SE image of fly ash concrete $(30 \%$ fly ash; $w / b=0.5)$ at 3 years. In general, fly ash concrete has a dense microstructure.

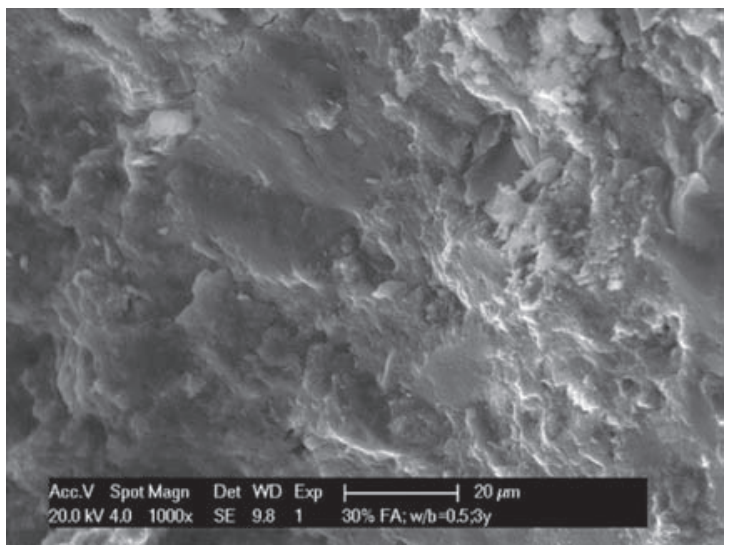

Figure 2. SE image of fly ash concrete $(30 \%$ fly ash; $w / b=0.5) 1000 \times$.

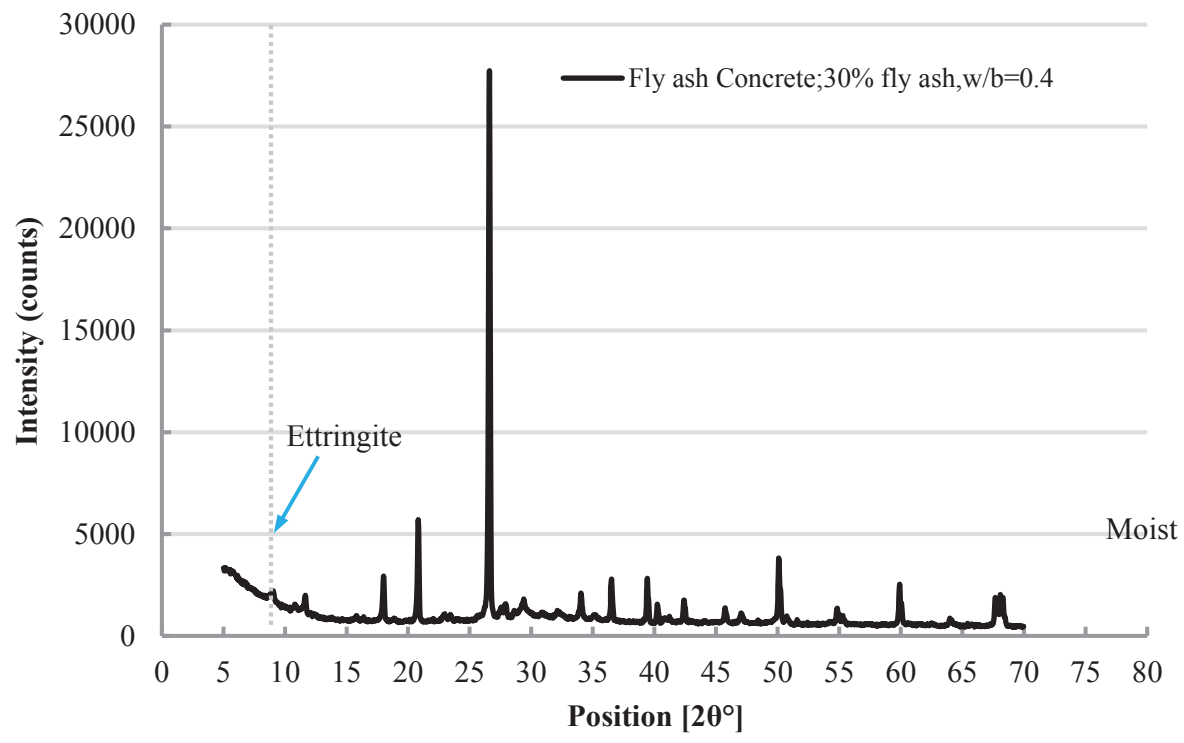

Figure 1. XRD pattern of fly ash concrete $(30 \%$ fly ash; $w / b=0.4)$ at 3 years. 
However, as shown in Figure 3, needle-shaped ettringite crystals are observed in voids. Ettringite crystals are also observed in the voids left by the reaction of the fly ash particles as shown in Figure 4.

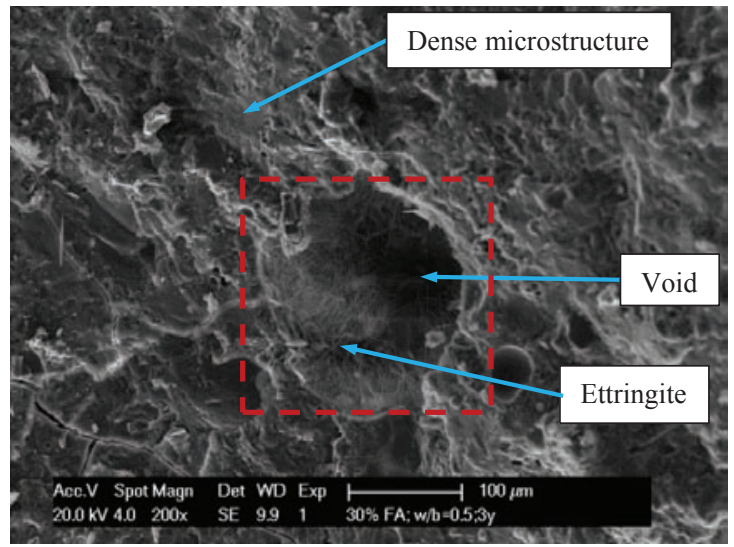

Figure 3. SE images of fly ash concrete (30\% fly ash; $w / b=0.5$; 3 years) with ettringite $200 \times$.

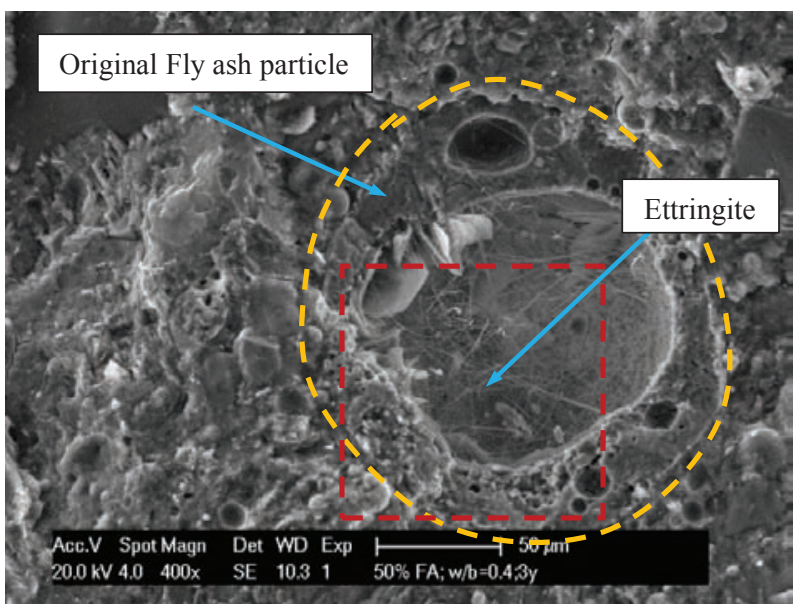

Figure 4. SE image of fly ash concrete $(50 \%$ fly ash; $w / b=0.4$; 3 years) with ettringite (a) $400 \times$.

\subsection{RCM results}

Figure 5 shows the chloride migration coefficient $\left(D_{\mathrm{RCM}}\right)$ of fly ash concrete with three w/c ratios.

As expected, the $D_{\text {RCM }}$ value of fly ash concrete decreases with increasing the curing age. After about 1 year, the $D_{\text {RCM }}$ value decreases slightly. The $w / c$ ratio has a significant influence on the $D_{R C M}$ value. The increase of $w / b$ ratio leads to a higher $D_{R C M}$ value at the same age of the concrete. However, there is no abnormal evolution of the $D_{R C M}$ value for fly ash concrete such as Portland cement concrete (Yu et al., 2015).

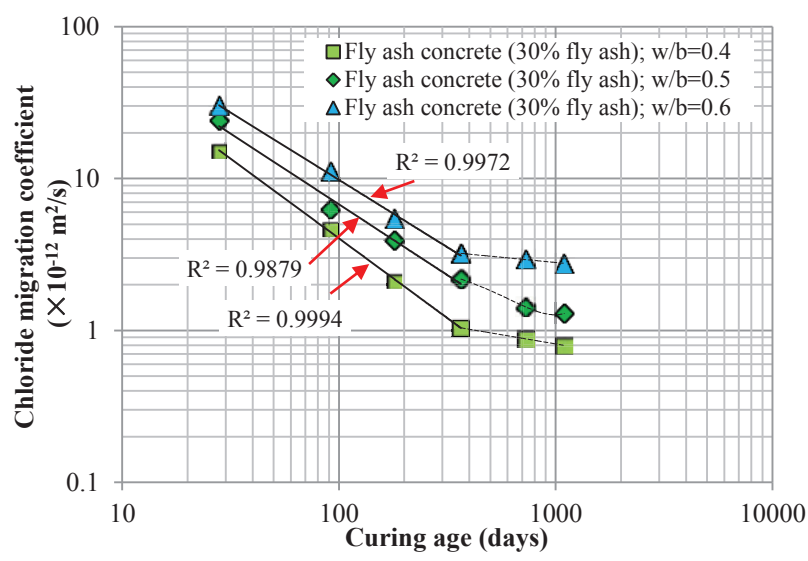

Figure 5. The $D_{R C M}$ values of fly ash concrete made with $30 \%$ fly ash with three $w / b$ ratios at different curing ages.

\section{DISCUSSIONS AND CONCLUSIONS}

From the results of XRD test and SE image observations, it is clear that ettringite forms in fly ash concrete at later ages ( 3 years). The reasons have been illustrated in previous paper (Yu et al., 2015).

As shown in Figures 3 and 4 , the ettringite tends to form in voids initially present in the paste and in the spaces left after the pozzolanic reaction fly ash particles. Since in fly ash concrete, more space is present for the formation of delayed ettringite, the expansion due to DEF and an associated probability of the micro-cracking are obviously strongly mitigated.

\section{REFERENCES}

Collepardi, M. (2001). Ettringite formation and sulfate attack on concrete. ACI Special Publication, 200, 21-38.

Ludwig, U., \& Heinz, D. (1985). Einflüsse auf die Schadreaktion in wärmebehandelten Betonen. Aachen, Germany: Festschrift Baustoffe, pp. 105-110.

NT Build 492 (1999). Concrete, mortar and cementbased repair materials: Chloride migration coefficient from non-steady-state migration experiments (UDC 691.32/691.53/691.54).

Stark, J., \& Bollmann, K. (1999). Delayed ettringite formation in concrete. Proceedings of Nordic Concrete Research Meetings Island. BauhausUniversity, Weimar, Germany, 4-28.

Yu, Z., Ye, G., \& Shen, X. (2015). Delayed ettringite formation in Portland cement concrete under moist curing conditions. Proceeding of 14th International Congress on the Chemistry of Cement (ICCC 2015), October 13-16, 2015, Beijing, China. 